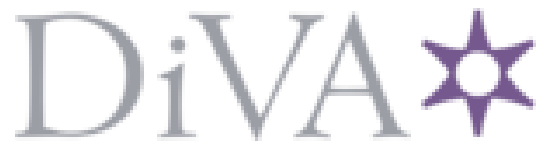

http://www.diva-portal.org

Preprint

This is the submitted version of a paper published in Cell Chemical Biology.

Citation for the original published paper (version of record):

Carnero Corrales, M A., Zinken, S., Konstantinidis, G., Rafehi, M., Abdelrahman, A. et al. (2021)

Thermal proteome profiling identifies the membrane-bound purinergic receptor $\mathrm{P}_{2} \mathrm{X}_{4}$ as a target of the autophagy inhibitor indophagolin

Cell Chemical Biology

https://doi.org/10.1016/j.chembiol.2021.02.017

Access to the published version may require subscription.

N.B. When citing this work, cite the original published paper.

Permanent link to this version:

http://urn.kb.se/resolve?urn=urn:nbn:se:umu:diva-188173 


\section{Thermal Proteome Profiling Identifies the Membrane-Bound Purinergic Receptor P2X4 as a Target of the Autophagy Inhibitor Indophagolin}

Marjorie A. Carnero Corrales, ${ }^{1,2}$ Sarah Zinken, ${ }^{1,2}$ Georgios Konstantinidis, ${ }^{3,6}$ Muhammad Rafehi, ${ }^{4}$ Aliaa Abdelrahman, ${ }^{4}$ Yao-Wen Wu, ${ }^{3,6}$ Petra Janning, ${ }^{1,2}$ Christa E. Müller, ${ }^{4}$ Luca Laraia, ${ }^{1,5 *}$ and Herbert Waldmann ${ }^{1,2 *}$

${ }^{1}$ Max Planck Institute of Molecular Physiology, Department of Chemical Biology, Otto-Hahn-Str. 11, 44227 Dortmund, Germany

${ }^{2}$ Technische Universität Dortmund, Faculty of Chemistry and Chemical Biology, Otto-Hahn-Str. 6, 44227 Dortmund, Germany

${ }^{3}$ Chemical Genomics Center of the Max Planck Society, Otto-Hahn-Str. 15, 44227 Dortmund, Germany ${ }^{4}$ PharmaCenter Bonn, Pharmaceutical Institute, Pharmaceutical Sciences Bonn (PSB), Pharmaceutical Chemistry I, University of Bonn, An der Immenburg 4, 53121 Bonn, Germany

${ }^{5}$ Department of Chemistry, Technical University of Denmark, Kemitorvet 207, Room 124, 2800 Kgs. Lyngby, Denmark

${ }^{6}$ Department of Chemistry, Umeå University, 90187, Umeå, Sweden

*Correspondence: luclar@kemi.dtu.dk (L.L.), herbert.waldmann@mpi-dortmund.mpg.de (H.W.)

\section{SUMMARY}

Signaling pathways are frequently activated through signal-receiving membrane proteins, and the discovery of new small molecules targeting these receptors may yield novel insights into their biology. However, due to their intrinsic properties, membrane protein targets often cannot be identified by means of established approaches, in particular, affinity-based proteomics, calling for the exploration of new methods. We report the identification of membrane receptors as putative targets of the new autophagy inhibitor indophagolin by means of thermal proteome profiling. Indophagolin was identified in a targetagnostic phenotypic assay as representative member of a new class of autophagy inhibitors. Thermal proteome profiling and subsequent biochemical validation identified the purinergic receptor P2X4 as a target of indophagolin, and subsequent investigations suggest that indophagolin targets further purinergic receptors. These results demonstrate that thermal proteome profiling may enable the de novo identification of membrane-bound receptors as cellular targets of bioactive small molecules.

\section{INTRODUCTION}

Chemical proteomics, in particular, the affinity-based enrichment and subsequent mass spectrometric identification of proteins, is arguably the most powerful and widely applied target identification technique for bioactive small molecules (Kapoor et al., 2016; Niphakis and Cravatt, 2014; Rix and Superti-Furga, 2009; Ziegler et al., 2013). However, this approach entails the equipment of the bioactive compound of interest with either a linker for attachment to an affinity matrix or with a photoactivatable tag for covalent target trapping (Ziegler et al., 2013). Such structural modifications also often require laborious structure-activity relationship (SAR) studies. In addition, chemical proteomics frequently fails to identify protein targets of low abundance and membrane-bound proteins, such as ion channels and $\mathrm{G}$ protein-coupled receptors (GPCRs), as these may lose their structural integrity during sample preparation (Frei et al., 2012; Wright and Sieber, 2016). These drawbacks may be overcome by means of the cellular thermal shift assay (CETSA), which monitors changes in protein thermal stability upon compound treatment in intact cells or lysates (Martinez Molina et al., 2013). More recently, this technique has been applied to monitor thermal stability across the whole proteome using quantitative mass spectrometry in a method termed thermal proteome profiling (TPP) (Dai et al. 2019; Franken et al., 2015; Friman 2020; Mateus et al., 2017; Savitski et al., 2014). TPP can be performed under conditions that enable the identification of membrane proteins and is a label-free approach, i.e., it does not require chemical modification of, e.g., a hit from a phenotypic screen. Despite its increasingly wide adoption as a method for identifying compound off-targets and assessing selectively, few examples of 
de novo target identification using TPP have been reported, and, to the best of our knowledge, identification of a membrane protein target for a hit obtained from an unbiased phenotypic assay using TPP has not been described previously.

Here we report the first application of TPP for the identification of membrane-bound receptors as the molecular targets of a small molecule identified in a target-agnostic phenotypic screen.

\section{RESULTS}

\section{Identification of Indophagolin by a Target-Agnostic Phenotypic Screen}

Because of the important role of autophagy in disease (Levine and Kroemer, 2008; Rubinsztein et al., 2012), a series of phenotypic assays to detect autophagic activity have been developed over the past decade, which have led to the discovery of multiple novel modulators of this cellular program. Moreover, many of these assays have been successfully employed as the starting point for target identification campaigns (Cho and Kwon, 2010; Galluzzi et al., 2017; Kaiser et al., 2019; Laraia et al., 2017; Laraia et al. 2019; Robke et al., 2018; Robke et al., 2017; Rubinsztein et al., 2012; Towers and Thorburn, 2016; $\mathrm{Xu}$ et al., 2017). Thus, for identification of new autophagy inhibitors, we selected an established phenotypic assay for autophagy inhibition that uses the human breast cancer cell line MCF7, stably expressing enhanced green fluorescent protein (eGFP) tagged to microtubule-associated protein light chain 3 (LC3) as a marker for autophagosome formation, as previously described (Konstantinidis et al., 2019; Kaiser et al., 2019; Laraia et al., 2017; Robke et al., 2018; Robke et al., 2017; Xu et al., 2017). The screen identified the indoline derivative indophagolin (1; Figure 1A) as a potent inhibitor of autophagy $\left(\mathrm{IC}_{50}=140 \pm 40 \mathrm{nM}\right.$; Figures 1B and 1C; Table 1) among our in-house compound collection of approximately 160,000 compounds. Indophagolin did not inhibit rapamycin-induced autophagosome formation, suggesting that it may act either upstream of mammalian target of rapamycin (mTOR) or through an mTOR-independent pathway (data not shown).

A series of validation assays was used to confirm the inhibitory effect of indophagolin on autophagy: In an orthogonal mCherry-eGFP-LC3 assay, which allows the visualization of autophagosomes and autolysosomes and thus allows differentiation from autophagosome-lysosome fusion inducers (Campbell and Choy, 2001; Mizushima et al., 2010), indophagolin reduced autophagosome numbers, but did not increase autolysosome numbers, suggesting that it inhibits autophagosome biogenesis and not maturation (Figures 1D, 1E, and 1F). Furthermore, indophagolin inhibited the accumulation of lipidated LC3 (LC3-II) and the degradation of p62 (both markers of autophagic flux) dose-dependently in amino acid-starved cells (Figure 1G), which is consistent with inhibition of autophagy. Finally, in agreement with data reported for autophagy inhibitors (Green and Levine, 2014; Laraia et al., 2017; Liu et al., 2011), apoptosis and viability assays in fed and starved cells showed that indophagolin is selectively toxic towards starved cells (Figure $1 \mathrm{H}$ and S1).

\section{Structure Activity Relationship Analysis}

To delineate an SAR for the modulation of indophagolin on autophagy, a collection of $>50$ structurally related analogues was prepared using a divergent synthetic route that allowed late-stage functionalization, leading to compound series $\mathbf{2}$ and $\mathbf{3}$, as well as additional analogues (Scheme S1). Evaluation of the generated compound collection in the phenotypic assay described above showed that replacement of the trifluoromethyl- and chloro-substituents on the sulfonamide aryl ring had a negative impact on the potency of this compound class, whereby only few bioisosteres were tolerated (2a, $\mathbf{2} \mathbf{b}$, 2d, 2g; Tables 1 and S1). The position of these substituents was also crucial, as compounds with a parasubstituent were less active (2c, 2e). Replacement of the cyclopropane functionality by similarly sized groups decreased the activity of the inhibitor (3a-c; Table 1; Table S2). C5-debrominated derivatives showed significant drops in potency (4). Finally, further replacements such as $N$-alkylation of the sulfonamide moiety as well as C6-modifications resulted in less potent inhibitors (Table S3). Based on these findings, we pursued indophagolin as the most potent example within this compound class. In addition, the steep SAR observed highlighted the need for a linker-free target identification approach for indophagolin. 
Identification of Purinergic Receptors Through TPP as Targets of Indophagolin

We explored TPP as a novel strategy for the identification of indophagolin's target(s). TPP relies on the change in thermal stability of a protein (measured by an increase or decrease in melting temperature, $\Delta \mathrm{T}_{\mathrm{m}}$ ) in the presence of an unmodified protein ligand (Franken et al., 2015; Mateus et al., 2017; Savitski et al., 2014). By combining this approach with tandem mass tag labeling and quantitative mass spectrometry-based proteomics, it is possible to determine melting temperatures for most proteins in the proteome, including membrane-bound proteins, without the need for modification of the compound of interest. This technique has been typically used for proof of target engagement in cell lysates but has only recently found use in target identification campaigns (Dziekan et al., 2019). TPP was performed for indophagolin using MCF7-eGFP-LC3 cell lysate in phosphate-buffered saline containing $0.4 \%$ NP40 (4-nonylphenyl-polyethylene glycol containing 40 ethylene glycol units), a detergent found previously to efficiently solubilize and enable the identification of membrane proteins (Mateus et al., 2017). While other detergents have also been found to solubilize select membrane proteins, a complete coverage of the membrane proteome with the use of a single detergent remains elusive (Kawatkar et al. 2019).

Among the 26 proteins found to be thermally stabilized or destabilized by indophagolin compared with the DMSO control, (Figure S2 and Table S4), the purinergic receptor P2X4 exhibited the largest stabilization $\left(\Delta \mathrm{T}_{\mathrm{m}}=+3.3{ }^{\circ} \mathrm{C}\right.$; Figure $\left.2 \mathrm{~A}\right)$ and was hence the initial focus of our target validation. Confirming the suitability of TPP to detect membrane-bound targets of bioactive small molecules was also a key criterion in further target prioritization. Stabilization of P2X4 by indophagolin was first measured in an intact-cell CETSA. Western blotting showed a highly reproducible thermal stabilization, similar to that observed through TPP (Figure 2B) (Martinez Molina et al., 2013). These findings suggest that intact-cell CETSA is an appropriate method for identifying and confirming membrane-bound targets of small molecules and may be more suitable than experiments with cell lysates, as they potentially allow the presence of membrane-bound proteins in their native state. Compared with indophagolin, the inactive analog $\mathbf{2 f}$ showed a similar, though slightly weaker stabilization of P2X4 (Figure S3). In a second validation step, an isothermal dose response fingerprinting (ITDRF) experiment with indophagolin in intact cells showed a dose-dependent stabilization of P2X4, with a half-maximal stabilization at $3.2 \mu \mathrm{M}$ (Figure $2 \mathrm{C}$ ). While this stabilization is an order of magnitude higher than the autophagy inhibitory activity, these findings are in line with previous results, which consistently show the requirement for high compound concentrations to clearly detect protein stabilization (Martinez Molina et al., 2016; Savitzki et al., 2014). One potential caveat of this data is the high temperatures $\left(73{ }^{\circ} \mathrm{C}\right)$ at which P2X4 melts in intact cells. Membrane integrity has been shown to not always be conserved at these temperatures (Martinez Molina et al., 2013; Miettinen et al., 2014), suggesting that caution is warranted in over-intepreting data of this type in the absence of additional validation experiments. In addition to P2X4, LAMTOR5, and RAB27A were also selected for validation due to their putative roles in autophagy (Bar-Peled et al. 2012). However, CETSA experiments failed to reproduce a clear shift in melting temperature, and these targets were not pursued further (data not shown).

\section{Validation of TPP Results and Identification of Additional Targets of Indophagolin}

The ionotropic purinergic receptor P2X4 is a trimeric ATP-gated cation channel of the purinergic receptor family, which is permeant for $\mathrm{Na}^{+}, \mathrm{K}^{+}$, and $\mathrm{Ca}^{2+}$. Interestingly, $\mathrm{P} 2 \mathrm{X} 4$ was not found to be stabilized by ATP in a recent TPP experiment in cell lysates (Sridharan et al. 2019). Although no direct link between P2X4 and autophagy has been demonstrated yet, numerous calcium-permeable channels have been reported to regulate this pathway (Kondratskyi et al., 2013). In order to confirm binding to the purinergic receptor and to determine indophagolin's selectivity toward $\mathrm{P} 2 \mathrm{X}$ receptors, the compound was subjected to assays monitoring the modulation of P2X ion channel activity (Abdelrahman et al., 2017). This investigation revealed that indophagolin antagonized the P2X4 receptor, confirming the TPP results, as well as the receptors P2X1 and P2X3 with low micromolar potency (Table 2 and Figure 2C). In contrast, the indophagolin-derived analog $\mathbf{2 f}$ (Table 1), which was inactive in the autophagy phenotypic screen, had no antagonistic effect on these receptors (Table S5). Importantly, other P2X receptors were not identified in the TPP experiments, and previous studies suggests that, contrary to P2X4, they are not currently part of the "meltome" in a range of cell lines including MCF7 (Jarzab et al 
2020; Miettinen et al., 2018). Although P2Rs have been identified in other cell lines and under specific experimental conditions, this suggests that they are challenging targets for TPP measurements.

Given its promiscuity toward P2X receptors, we investigated whether indophagolin interacted with purinergic receptors more broadly. To this end, indophagolin was subjected to a calcium mobilization assay that monitors the activity of P2Y GPCRs (Rafehi et al., 2017). Indophagolin, but not the inactive analog 2f, was shown to antagonize the $\mathrm{G}_{\mathrm{q}}$ protein-coupled $\mathrm{P} 2 \mathrm{Y}_{4}, \mathrm{P} 2 \mathrm{Y}_{6}$, and $\mathrm{P} 2 \mathrm{Y}_{11}$ receptors with potencies in the low micromolar range (Tables 2 and S5; Figure 2D), thereby suggesting that indophagolin may inhibit autophagy by engaging several receptors. Of note, current evidence on the role of $\mathrm{P} 2 \mathrm{Y}$ receptors in autophagy is conflicting, with some results suggesting that $\mathrm{P} 2 \mathrm{Y} 13$ may promote autophagy (Chatterjee et al. 2012), while others implying that activation of P2Y receptors more broadly using uridine 5'-triphosphate (UTP) does not induce autophagy (Biswas et al. 2008). To further determine indophagolin's target selectivity, we investigated whether the compound might target additional GPCRs, as this receptor family plays an important role in autophagy (Wauson et al., 2014). To streamline this search, we subjected the compound to computational target prediction analyses, including SwissTargetPrediction (Gfeller et al., 2013), SEA (Keiser et al., 2007), and a structure similarity search in SciFinder (SciFinder, 2004) and the ChemBL database (Bento et al., 2014). Indeed, target prediction revealed that indophagolin might act as a modulator of additional GPCRs, in particular, 5-hydroxytryptamine (5-HT) receptors, based on the close structural similarity between indophagolin and known 5-HT receptor antagonists (Figure S4). Cell-based assays confirmed that indophagolin had a strong antagonistic effect on serotonin receptor $5-\mathrm{HT}_{6}\left(\mathrm{IC}_{50}=1.0 \mu \mathrm{M}\right)$ and a moderate effect on receptors 5- $\mathrm{HT}_{1 \mathrm{~B}}, 5-\mathrm{HT}_{2 \mathrm{~B}}, 5-\mathrm{HT}_{4 \mathrm{e}}$, and 5- $\mathrm{HT}_{7}$ (Figure $\mathrm{S} 5$ ). Evaluation of selective $\mathrm{P} 2 \mathrm{X}, \mathrm{P} 2 \mathrm{Y}$, and 5-HT antagonists in the autophagy phenotypic screen described above showed that none of these compounds individually inhibited autophagy (Tables S6 and S7), thereby strengthening the notion that the autophagy-modulating effect of indophagolin may in fact be due to antagonism of multiple membranebound proteins. If confirmed, this would, to the best of our knowledge, be the first example of antagonism of multiple receptors leading to autophagy modulation. Conclusive measurement of binding between indophagolin and P2 receptors and the elucidation of the relationship between P2Rs and autophagy will be the subject of further investigations.

\section{DISCUSSION}

TPP was successfully employed as a novel label-free strategy for the identification of membrane-bound receptors as putative targets of small molecules. Using an exemplifying target-agnostic phenotypic screen, indophagolin was discovered as an inhibitor of autophagy. TPP led to the identification of the membrane-located purinergic receptor $\mathrm{P} 2 \mathrm{X} 4$ as a putative target, which was validated using CETSA, ITDRF and biochemical assays. Additionally, a more general inhibition of purinergic receptors was observed, suggesting that indophagolin may act through a polypharmacological mechanism to inhibit autophagy, which is in line with the steep structure-activity profile of the compound. Further work is needed to confirm this unprecedented mode-of-action. Previous applications of TPP reported in the literature have demonstrated that this method can be successfully employed to monitor the thermal stability of membrane-bound proteins (Reinhard et al., 2015). However, TPP has not been employed for the de novo target identification of a membrane protein by a small molecule to date. Thus, our findings constitute the first example of the use of TPP to identify the membrane-associated target of a hit from an unbiased phenotypic screen.

The identification of membrane proteins as small-molecule targets represents a significant challenge for the majority of target identification techniques. The potential for TPP to identify membrane proteins without the need to functionalize the molecule in question with a handle suggests that TPP may well be recommendable as general target identification strategy. Despite its advantages, it is important to highlight the limitations of this method. (De)stabilization of a protein may not result from direct binding, but may occur through a complex. Furthermore, false negatives are possible, as certain targets are not (de)stabilized by interacting ligands or the interaction is lost at higher temperatures, masking a binding event. In this regard, the application of orthogonal target ID techniques is essential, as exemplified by the identification of serotonin receptors as additional targets for indophagolin using computational target prediction methods. The combination of orthogonal target identification techniques that do not rely in 
pre-functionalization of a hit compound provides a toolkit for rapidly tackling one of the traditional bottlenecks in drug discovery and chemical biology.

\section{SIGNIFICANCE}

Target identification strategies that do not rely on pre- functionalization of a bioactive compound are highly desirable. They enable the identification of targets for compounds that are synthetically complex, are available in low quantities, or do not contain a suitable site for immobilization and avoid extensive exploration of the structure-activity relationship of a compound class. Such a label-free target identification strategy that is also able to interrogate most of the proteome, including membrane proteins, may define the state-of-the-art. This work demonstrates that thermal proteome profiling can meet all of the above criteria. The identification of the membrane-bound receptor P2X4 as a target of the new autophagy inhibitor indophagolin demonstrates the wide scope and applicability of this technique, in particular, extending to membrane-bound proteins, which often escape their identification by established target identification methods.

\section{STAR $\star M E T H O D S$}

Detailed methods are provided in the online version of this paper and include the following:

- KEY RESOURCES TABLE

- CONTACT FOR REAGENT AND RESOURCE SHARING

- METHOD DETAILS

- Mammalian Cell Culture

○ High-Content Screening for Autophagy Inhibitors

○ Confocal Live-Cell Imaging of MCF7-mCherry-eGFP-LC3 Cells

- Immunoblotting for Autophagy Inhibition

○ Selective Viability Assay

- Cellular Thermal Shift Assay and Thermal Proteome Profiling

- QUANTIFICATION AND STATISTICAL ANALYSIS

- DATA AND CODE AVAILABILITY

SUPPLEMENTAL INFORMATION

Supplemental Information can be found online at https://doi.org/10.1016/j. chembiol.2019.XX.XXX.

\section{ACKNOWLEDGEMENTS}

This work was supported by the Max Planck Society. Y.-W.W acknowledges funding from the Deutsche Forschungsgemeinschaft (grant No.: SPP 1623), the Behrens Weise Stiftung, the European Research Council (ChemBioAP), Vetenskapsrådet (grant No. 2018-04585), and The Knut and Alice Wallenberg Foundation. M.C.C. is grateful to the Fonds der chemischen Industrie for a Kekule fellowship and the Swiss National Science Foundation for a Doc.mobility fellowship. L.L. was supported by a fellowship from the Alexander von Humboldt Stiftung. C.E.M. was supported by the DFG (GRK 1873) and the BMBF (Neuroallianz). We thank Dr. Sonja Sievers and the Compound Management and Screening Center (COMAS), Dortmund, Germany, for compound screening.

\section{AUTHOR CONTRIBUTIONS}

M.C.C carried out the chemical synthesis, target identification and early validation experiments. S.Z. carried out the in-cell CETSA and ITDRF experiments. G.K. and L.L. carried out indophagolin autophagy validation experiments. M.R. and A.A. carried out purinergic receptor assays. M.C.C. P.J. and L.L. carried out the proteomics data analysis. Y.-W.W. supervised autophagy experiments. C.M. supervised purinergic receptor experiments. L.L. and H.W. coordinated the project. M.C.C., L.L., and H.W. wrote the manuscript with input from all authors.

\section{DECLARATION OF INTERESTS}

The authors declare no conflict of interest. 


\section{REFERENCES}

Abdelrahman, A., Namasivayam, V., Hinz, S., Schiedel, A.C., Köse, M., Burton, M., El-Tayeb, A., Gillard, M., Bajorath, J., de Ryck, M., et al. (2017). Characterization of P2X4 receptor agonists and antagonists by calcium influx and radioligand binding studies. Biochem Pharmacol 125, 41-54.

Bar-Peled, L., Schweitzer, L.D., Zoncu, R. and Sabatini, D.M., (2012). Ragulator is a GEF for the rag GTPases that signal amino acid levels to mTORC1. Cell, 150, 1196-1208.

Bento, A.P., Gaulton, A., Hersey, A., Bellis, L.J., Chambers, J., Davies, M., Krüger, F.A., Light, Y., Mak, L., McGlinchey, S., et al. (2014). The ChEMBL bioactivity database: an update. Nucleic Acids Res 42, D1083-D1090.

Biswas, D., Qureshi, O.S., Lee, W.Y., Croudace, J.E., Mura, M. and Lammas, D.A., (2008). ATPinduced autophagy is associated with rapid killing of intracellular mycobacteria within human monocytes/macrophages. BMC immunology, 9, 1-10.

Bradford, M.M. (1976). A rapid and sensitive method for the quantitation of microgram quantities of protein utilizing the principle of protein-dye binding. Anal Biochem 72, 248-254.

Campbell, T.N., and Choy, F.Y.M. (2001). The Effect of pH on Green Fluorescent Protein: a Brief Review. Mol Biol Today 2, 1-4.

Chatterjee, C. and Sparks, D.L., (2012). Extracellular nucleotides inhibit insulin receptor signaling, stimulate autophagy and control lipoprotein secretion. PloS one, 7, e36916.

Cho, Y.S., and Kwon, H.J. (2010). Control of autophagy with small molecules. Arch Pharmacal Res 33, 1881-1889.

Cox, J., and Mann, M. (2008). MaxQuant enables high peptide identification rates, individualized p.p.b.range mass accuracies and proteome-wide protein quantification. Nat Biotechnol 26, 1367-1372.

Dai, L., Prabhu, N., Yu, L.Y., Bacanu, S., Ramos, A.D. and Nordlund, P., (2019). Horizontal cell biology: monitoring global changes of protein interaction states with the proteome-wide cellular thermal shift assay (CETSA). Ann Rev Biochem, 88, 383-408.

Dziekan, J.M., Yu, H., Chen, D., Dai, L., Wirjanata, G., Larsson, A., Prabhu, N., Sobota, R.M., Bozdech, Z., and Nordlund, P. (2019). Identifying purine nucleoside phosphorylase as the target of quinine using cellular thermal shift assay. Science translational medicine 11, eaau3174.

Franken, H., Mathieson, T., Childs, D., Sweetman, G.M., Werner, T., Tögel, I., Doce, C., Gade, S., Bantscheff, M., Drewes, G., et al. (2015). Thermal proteome profiling for unbiased identification of direct and indirect drug targets using multiplexed quantitative mass spectrometry. Nature protocols 10 , 1567-1593.

Frei, A.P., Jeon, O.-Y., Kilcher, S., Moest, H., Henning, L.M., Jost, C., Plückthun, A., Mercer, J., Aebersold, R., Carreira, E.M., et al. (2012). Direct identification of ligand-receptor interactions on living cells and tissues. Nat Biotechnol 30, 997-1001.

Friman, T., 2020. Mass spectrometry-based Cellular Thermal Shift Assay (CETSA $\left.{ }^{\circledR}\right)$ for target deconvolution in phenotypic drug discovery. Bioorg Med Chem, 28, 115174.

Galluzzi, L., Bravo-San Pedro, J.M., Levine, B., Green, D.R., and Kroemer, G. (2017). Pharmacological modulation of autophagy: therapeutic potential and persisting obstacles. Nat Rev Drug Discov 16, 487511.

Gfeller, D., Michielin, O., and Zoete, V. (2013). Shaping the interaction landscape of bioactive molecules. Bioinformatics 29, 3073-3079.

Green, D.R., and Levine, B. (2014). To be or not to be? How selective autophagy and cell death govern cell fate. Cell 157, 65-75.

Jarzab, A., Kurzawa, N., Hopf, T., Moerch, M., Zecha, J., Leijten, N., Bian, Y., Musiol, E., Maschberger, M., Stoehr, G. and Becher, I., 2020. Meltome atlas - thermal proteome stability across the tree of life. Nat Methods, 17, 495-503.

Kaiser, N., Corkery, D., Wu, Y., Laraia, L., and Waldmann, H. (2019). Modulation of autophagy by the novel mitochondrial complex I inhibitor Authipyrin. Bioorg Med Chem 27, 2444-2448.

Kapoor, S., Waldmann, H., and Ziegler, S. (2016). Novel approaches to map small molecule-target interactions. Bioorg Med Chem 24, 3232-3245. 
Kawatkar, A., Schefter, M., Hermansson, N.O., Snijder, A., Dekker, N., Brown, D.G., Lundbäck, T., Zhang, A.X. and Castaldi, M.P., (2019). CETSA beyond soluble targets: a broad application to multipass transmembrane proteins. ACS Chem Biol, 14, 1913-1920.

Keiser, M.J., Roth, B.L., Armbruster, B.N., Ernsberger, P., Irwin, J.J., and Shoichet, B.K. (2007). Relating protein pharmacology by ligand chemistry. Nat Biotechnol 25, 197-206.

Kondratskyi, A., Yassine, M., Kondratska, K., Skryma, R., Slomianny, C., and Prevarskaya, N. (2013). Calcium-permeable ion channels in control of autophagy and cancer. Front Physiol 4, 272.

Konstantinidis, G., Sievers, S., and Wu, Y.W. (2019). Identification of Novel Autophagy Inhibitors via Cell-Based High-Content Screening. Methods Mol Biol 1854, 187-195.

Laraia, L., Ohsawa, K., Konstantinidis, G., Robke, L., Wu, Y.-W., Kumar, K., and Waldmann, H. (2017). Discovery of Novel Cinchona-Alkaloid-Inspired Oxazatwistane Autophagy Inhibitors. Angew Chem Int Ed 56, 2145-2150.

Laraia, L., Friese, A., Corkery, D.P., Konstantinidis, G., Erwin, N., Hofer, W., Karatas, H., Klewer, L., Brockmeyer, A., Metz, M. et al., (2019). The cholesterol transfer protein GRAMD1A regulates autophagosome biogenesis. Nat Chem Biol, 15, 710-720.

Levine, B., and Kroemer, G. (2008). Autophagy in the pathogenesis of disease. Cell 132, 27-42.

Liu, J., Xia, H., Kim, M., Xu, L., Li, Y., Zhang, L., Cai, Y., Norberg, H.V., Zhang, T., Furuya, T., et al. (2011). Beclin 1 controls the levels of p53 by regulating the deubiquitination activity of USP10 and USP13. Cell 147, 223-234.

Martinez Molina, D., Jafari, R., Ignatushchenko, M., Seki, T., Larsson, E.A., Dan, C., Sreekumar, L., Cao, Y., and Nordlund, P. (2013). Monitoring drug target engagement in cells and tissues using the cellular thermal shift assay. Science $341,84-87$.

Martinez Molina, D., and Nordlund, P. (2016). The cellular thermal shift assay: a novel biophysical assay for in situ drug target engagement and mechanistic biomarker studies. Ann. Rev. Pharm. Tox., 56, 141-161.

Mateus, A., Määttä, T.A., and Savitski, M.M. (2017). Thermal proteome profiling: unbiased assessment of protein state through heat-induced stability changes. Proteome Science 15, 13.

Miettinen, T. P., and Björklund, M. (2014). NQO2 is a reactive oxygen species generating off-target for acetaminophen. Mol. Pharm., 11(12), 4395-4404.

Miettinen, T. P., Peltier, J., Härtlova, A., Gierliński, M., Jansen, V. M., Trost, M., \& Björklund, M. (2018). Thermal proteome profiling of breast cancer cells reveals proteasomal activation by CDK $4 / 6$ inhibitor palbociclib. EMBO J., 37(10), e98359.

Mizushima, N., Yoshimori, T., and Levine, B. (2010). Methods in mammalian autophagy research. Cell 140, 313-326.

Niphakis, M.J., and Cravatt, B.F. (2014). Enzyme inhibitor discovery by activity-based protein profiling. Annu Rev Biochem 83, 341-377.

Rafehi, M., Malik, E.M., Neumann, A., Abdelrahman, A., Hanck, T., Namasivayam, V., Müller, C.E., and Baqi, Y. (2017). Development of Potent and Selective Antagonists for the UTP-Activated P2Y4 Receptor. J Med Chem 60, 3020-3038.

Reinhard, F.B., Eberhard, D., Werner, T., Franken, H., Childs, D., Doce, C., Savitski, M.F., Huber, W., Bantscheff, M., Savitski, M.M., et al. (2015). Thermal proteome profiling monitors ligand interactions with cellular membrane proteins. Nat Methods 12, 1129-1131.

Rix, U., and Superti-Furga, G. (2009). Target profiling of small molecules by chemical proteomics. Nat Chem Biol 5, 616-624.

Robke, L., Futamura, Y., Konstantinidis, G., Wilke, J., Aono, H., Mahmoud, Z., Watanabe, N., Wu, Y.W., Osada, H., Laraia, L., et al. (2018). Discovery of the novel autophagy inhibitor aumitin that targets mitochondrial complex I. Chem Sci 9, 3014-3022.

Robke, L., Laraia, L., Carnero Corrales, M.A., Konstantinidis, G., Muroi, M., Richters, A., Winzker, M., Engbring, T., Tomassi, S., Watanabe, N., et al. (2017). Phenotypic Identification of a Novel Autophagy Inhibitor Chemotype Targeting Lipid Kinase VPS34. Angew Chem Int Ed Engl 56, 81538157. 
Rubinsztein, D.C., Codogno, P., and Levine, B. (2012). Autophagy modulation as a potential therapeutic target for diverse diseases. Nat Rev Drug Discov 11, 709-730.

Savitski, M.M., Reinhard, F.B., Franken, H., Werner, T., Savitski, M.F., Eberhard, D., Martinez Molina, D., Jafari, R., Dovega, R.B., Klaeger, S., et al. (2014). Tracking cancer drugs in living cells by thermal profiling of the proteome. Science 346, 1255784.

SciFinder. Available at http://scifinder.cas.org, Chemical Abstracts Service: Columbus, OH (Oct. 2013). Sridharan, S., Kurzawa, N., Werner, T., Günthner, I., Helm, D., Huber, W., Bantscheff, M. and Savitski, M.M., (2019). Proteome-wide solubility and thermal stability profiling reveals distinct regulatory roles for ATP. Nat Commun, 10, 1-13.

Towers, C.G., and Thorburn, A. (2016). Therapeutic Targeting of Autophagy. EBioMedicine 14, 1523.

Wauson, E.M., Dbouk, H.A., Ghosh, A.B., and Cobb, M.H. (2014). G protein-coupled receptors and the regulation of autophagy. Trends Endocrinol Metab 25, 274-282.

Wright, M.H., and Sieber, S.A. (2016). Chemical proteomics approaches for identifying the cellular targets of natural products. Nat Prod Rep 33, 681-708.

Xu, H., Laraia, L., Schneider, L., Louven, K., Strohmann, C., Antonchick, A.P., and Waldmann, H. (2017). Highly Enantioselective Catalytic Vinylogous Propargylation of Coumarins Yields a Class of Autophagy Inhibitors. Angew Chem Int Ed Engl 56, 11232-11236.

Ziegler, S., Pries, V., Hedberg, C., and Waldmann, H. (2013). Target identification for small bioactive molecules: finding the needle in the haystack. Angew Chem Int Ed 52, 2744-2792. 


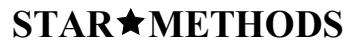

KEY RESOURCES TABLE

\begin{tabular}{lll}
\hline REAGENT or RESOURCE & SOURCE & IDENTIFIER \\
\hline $\begin{array}{l}\text { Chemicals, } \begin{array}{l}\text { Peptides, } \\
\text { Recombinant Proteins }\end{array} \\
\text { DMEM }\end{array}$ & and & \\
MEM & PAN Biotech & Cat\# P04-03550 \\
Fetal bovine serum & Invitrogen & Cat\# P04-08500 \\
Sodium pyruvate & PAN Biotech & Cat\# 10500-084 \\
Non-essential amino acids & PAN Biotech & Cat\# P04-43100 \\
Bovine insulin & Sigma Aldrich & Cat\# P08-32100 \\
Hoechst & Sigma Aldrich & Cat\# I9278 \\
Phenol red & Invitrogen & Cat\# B2261-25mg \\
EBSS & Sigma & N/A \\
WST-1 reagent & Roche & N/A \\
Bradford reagent & Bio-Rad laboratories & N/A \\
TMT10plex & Thermo Fisher Scientific & N/A \\
\hline Expering & & Cat\# 90110
\end{tabular}

Experimental Models: Cell Lines

\begin{tabular}{|c|c|c|}
\hline MCF7 & Sigma-Aldrich & Cat\# 800021 \\
\hline \multicolumn{3}{|l|}{ Software and Algorithms } \\
\hline MetaXpress Cell Analysis Software & Molecular Devices & N/A \\
\hline $\begin{array}{l}\text { Green and Red Puncta Colocalization } \\
\text { macro }\end{array}$ & $\begin{array}{l}\text { Ruben K. Dagda, University of } \\
\text { Nevada School of Medicine, } \\
\text { Pharmacology Department; Daniel } \\
\text { Shiwarski, Carneggie Mellon } \\
\text { University; Charleen T Chu, } \\
\text { University of Pittsburgh }\end{array}$ & N/A \\
\hline MaxQuant software & Cox and Mann, 2008 & N/A \\
\hline \multicolumn{3}{|l|}{ Other } \\
\hline $\begin{array}{lll}\text { AxioVert } & 200 \mathrm{M} & \text { fluorescence } \\
\text { microscope } & & \\
\end{array}$ & Zeiss & N/A \\
\hline $\begin{array}{l}\text { Leica SP5 AOBS confocal } \\
\text { microscope }\end{array}$ & Leica & N/A \\
\hline $\begin{array}{l}63 \mathrm{x} / 1.4 \mathrm{HCX} \text { Plan Apo oil immersion } \\
\text { lens }\end{array}$ & & N/A \\
\hline
\end{tabular}




\begin{tabular}{|c|c|c|}
\hline Beckman DTX-880 & Beckman Coulter, Germany & $\mathrm{N} / \mathrm{A}$ \\
\hline PCR cycler & $\begin{array}{l}\text { Eppendorf Mastercycler ep gradient } \\
\mathrm{S}\end{array}$ & $\mathrm{N} / \mathrm{A}$ \\
\hline U3000 capHPLC- System & Thermo Fisher Scientific, Germany & N/A \\
\hline UltiMateTM 3000 RSLCnano system & Thermo Fisher Scientific, Germany & N/A \\
\hline Nanospray Flex Ion Source & Thermo Fisher Scientific, Germany & N/A \\
\hline SilicaTip & New Objective, Woburn, MA, USA & $\mathrm{N} / \mathrm{A}$ \\
\hline Pre-column cartridge & Dionex, Germany & N/A \\
\hline $\begin{array}{l}\text { PepMap100 RSLC C18 nano-HPLC } \\
\text { column }\end{array}$ & Dionex, Ge & N/A \\
\hline
\end{tabular}

\section{CONTACT FOR REAGENT AND RESOURCE SHARING}

Further information and requests for resources and reagents should be directed to and will be fulfilled by the Lead Contacts, Luca Laraia (luclar@kemi.dtu.dk) and Herbert Waldmann (herbert.waldmann@mpi-dortmund.mpg.de).

\section{METHOD DETAILS}

\section{Mammalian Cell Culture}

All the work involving living mammalian cells was performed with sterile equipment, media, and solutions in cell culture-approved benches. The generated waste was collected and sterilized by autoclaving at $134{ }^{\circ} \mathrm{C}$ for $15 \mathrm{~min}$.

Human breast cancer MCF7 cells stably transfected with eGFP-LC3 (MCF7-eGFP-LC3) were cultured at $37{ }^{\circ} \mathrm{C}$ with $5 \% \mathrm{CO}_{2}$ using Eagle's DMEM or MEM containing $10 \%$ fetal bovine serum, $1 \%$ sodium pyruvate, $1 \%$ non-essential amino acids, $0.01 \mathrm{mg} / \mathrm{mL}$ bovine insulin, and $200 \mu \mathrm{g} / \mathrm{mL} \mathrm{G} 418$ as the medium. Untransfected MCF7 cells were incubated in Eagle's MEM with the same additives as used for transfected cells but without G418.

\section{High-Content Screening for Autophagy Inhibitors}

The phenotypic autophagy screen used MCF7-eGFP-LC3 cells. A total of 10,000 cells per well were seeded in $100 \mu \mathrm{L}$ medium in 96-well Corning ${ }^{\circledR}$ CellBIND ${ }^{\circledR}$ plates (cat\# 3340) and incubated overnight. Cells were washed with $50 \mu \mathrm{L}$ phosphate-buffered saline (PBS) followed by a final aspiration of the washing buffer. Autophagy was induced by addition of $100 \mu \mathrm{L}$ compound solution at multiple concentrations ( $10 \mu \mathrm{m}$ to $4.6 \mathrm{~nm}$ in 1:3 dilution steps) in chloroquine-containing EBSS medium $(50 \mu \mathrm{m})$. After incubation for $3 \mathrm{~h}$, cells were fixed by addition of $25 \mu \mathrm{L} 4 \%$ formaldehyde in PBS $+1: 500$ Hoechst (stock: $1 \mathrm{mg} / \mathrm{mL}$ ) and incubation for $20 \mathrm{~min}$ at room temperature. Cells were then washed twice with and stored in $100 \mu \mathrm{L}$ PBS. Four images per well were taken with an automated AxioVert 200M fluorescence microscope at 20x. Automated image analysis was performed using a modified configuration of the granularity assay (approx. granule min. and max. width: 0.4 and $5 \mu \mathrm{m}$ resp.; approx. nuclei min. and max. width: 6 and $20 \mu \mathrm{m}$, resp.; intensity of granules and nuclei above background: 300 and 40 gray levels, resp.) of MetaXpress Cell Analysis Software. Inhibition of autophagy was quantified by calculating the number of granules per nucleus and normalized to the compound-free controls.

Confocal Live-Cell Imaging of MCF7-mCherry-eGFP-LC3 Cells

After seeding of 400,000 MCF7-mCherry-eGFP-LC3 cells (kind gift of Sharon Tooze) in glass-bottom dishes (MatTek, Ashland) and overnight incubation, media were removed and replaced with $2 \mathrm{~mL}$ of the indicated treatment media containing appropriate compounds. After incubation for $3 \mathrm{~h}$, live cell imaging was performed in MEM without phenol red or EBSS by using an inverted confocal microscope 
Leica SP5 AOBS equipped with a 63x/1.4 HCX Plan Apo oil immersion lens and a temperaturecontrolled hood at $37^{\circ} \mathrm{C}$ and $5 \% \mathrm{CO}_{2}$. Green and Red Puncta Colocalization macro was used to analyze mCherry-eGFP-LC3 puncta.

\section{Immunoblotting for Autophagy Inhibition}

MCF7-eGFP-LC3 cells ( $2 \mathrm{~mL}$ for 6-well, $1 \mathrm{~mL}$ for 12-well plates; 100,000 cells $/ \mathrm{mL}$ ) were seeded in 6or 12-well plates and incubated overnight. The medium was replaced by fresh MEM, EBSS, or the respective compounds MEM or EBSS. The cells were then incubated for $3 \mathrm{~h}$, the medium was removed, and the cells washed with PBS (1 mL for 6-well plates, $0.5 \mathrm{~mL}$ for 12 -well plates). Cell lysis was performed by adding Laemmli buffer (1X), followed by stringent scraping with Cell Scrapers. The mixture was collected and homogenized by sonification. The protein concentration was determined using the DC assay, and all samples were diluted to the same concentration. SDS sample buffer was added $(20 \% \mathrm{v} / \mathrm{v})$, and the proteins were denatured by heating at $95{ }^{\circ} \mathrm{C}$ for $5 \mathrm{~min}$. The samples were snapfrozen and stored at $-80^{\circ} \mathrm{C}$ until further use. The proteins were then separated by SDS-PAGE and the LC3-B and p62 levels analyzed by western blot using $\beta$-actin as a loading control.

\section{Selective Viability Assay}

For fed conditions, 4,000 MCF7-eGFP-LC3 cells in $100 \mu \mathrm{L}$ medium were seeded in a clear flat-bottom 96-well plate and incubated overnight. For starved conditions, 7,000 cells in $100 \mu \mathrm{L}$ medium were used. The media were removed gently, and cells were washed with PBS $(100 \mu \mathrm{L})$. The PBS was replaced with $100 \mu \mathrm{L}$ of normal media (fed conditions) or EBSS (starved). Test compounds at a concentration of $6 \mathrm{x}$ the desired final concentration in $20 \mu \mathrm{L}$ of the appropriate medium were added. Cells were incubated for $48 \mathrm{~h}$. At this point $10 \mu \mathrm{L}$ of WST-1 reagent was added to each well. The absorbance was measured with a Beckman DTX-880 plate reader at $450 / 690 \mathrm{~nm}$. Absorbance measurements were performed after $20,30,40,50,60 \mathrm{~min}$ of addition of indophagolin. Good measurements are considered when absorbance of the DMSO control is around 1.00. $\mathrm{IC}_{50}$ values were calculated using GraphPad Prism using DMSO (negative) and nocodazole (10 $\mu \mathrm{M}$, positive) as controls.

\section{Cellular Thermal Shift Assay and Thermal Proteome Profiling 1) Lysate Preparation}

For CETSA and TPP experiments, MCF7-eGFP-LC3 cells were cultured according to the procedures described above. For one T175 flask, the cells were tripsinized with $3 \mathrm{~mL}$ trypsin/EDTA, resuspended in MEM medium $(10 \mathrm{~mL})$, and centrifuged at $150 \times \mathrm{g}$ and $4{ }^{\circ} \mathrm{C}$ for $5 \mathrm{~min}$. The medium was removed, and the cell pellet was washed with ice-cold PBS $(2 \times 25 \mathrm{~mL}$ and $1 \times 10 \mathrm{~mL}$, centrifugation at $150 \times \mathrm{g}$ and $4{ }^{\circ} \mathrm{C}$ for $5 \mathrm{~min}$ each time). The pellet was resuspended in PBS containing the nonylphenyl polyethylene glycol (NP-40 alternative, $1.5 \mathrm{~mL}, 0.4 \% \mathrm{v} / \mathrm{v}$ ), used to enhance membrane protein solubilization. The cells were lysed via a freeze-thaw cycle $(4 \mathrm{x})$. The insoluble components were separated by centrifugation for $20 \min 4{ }^{\circ} \mathrm{C}$ and $100,000 \times g$ using polycarbonate tubes in an ultracentrifuge. Protein concentration was determined using the Bradford method (Bradford, 1976) with the Bradford reagent. After dilution to $2 \mathrm{mg} / \mathrm{mL}$, the lysate was snap-frozen and stored at $-80{ }^{\circ} \mathrm{C}$ until further use.

\section{2) Thermal Proteome Profiling}

The cell lysate was thawed and split into two vials $(1.4 \mathrm{~mL}$ each). One sample was treated with indophagolin in DMSO and the other only with DMSO, resulting in a final concentration of $2.5 \mu \mathrm{M}$ and $1 \% \mathrm{v} / \mathrm{v}$ DMSO. The samples were incubated at rt for $30 \mathrm{~min}$, each split into 10 aliquots of $120 \mu \mathrm{L}$ and subjected to heating at different temperatures in a gradient PCR cycler for $3 \mathrm{~min}$. The temperature gradient ranged from $37-67^{\circ} \mathrm{C}$, while one vehicle sample was always heated in parallel with one compound sample. The samples were then cooled to $4{ }^{\circ} \mathrm{C}$, centrifuged for 20 min at $4{ }^{\circ} \mathrm{C}$ and $100,000 x$ g. $75 \mu \mathrm{L}$ of the supernatant were transferred into low-binding Eppendorf tubes.

Trypsin Digest

After the thermal shift assay, $75 \mu \mathrm{L}$ of each aliquot were treated with freshly prepared TEAB buffer $(75 \mu \mathrm{L}, 100 \mathrm{mM})$ and reducing buffer $(200 \mathrm{mM}$ TCEP, $0.2 \mathrm{mM} \mathrm{TEAB}, 7.5 \mu \mathrm{L})$ and incubated for $1 \mathrm{~h}$ at $55^{\circ} \mathrm{C}$ and $350 \mathrm{rpm}$. The remaining $25 \mu \mathrm{L}$ were snap-frozen, stored at $-80^{\circ} \mathrm{C}$ for immunoblotting. A freshly prepared alkylation solution (iodoacetamide in reducing buffer, $375 \mathrm{mM}, 7.5 \mu \mathrm{L}$ ) was added to 
each sample, and incubation was continued for $30 \mathrm{~min}$ in darkness. Afterwards, pre-chilled acetone (ca. $900 \mu \mathrm{L}$ ) was added, and the proteins were allowed to precipitate overnight at $-20^{\circ} \mathrm{C}$. The samples were centrifuged for $10 \mathrm{~min}$ at $4{ }^{\circ} \mathrm{C}$ and $8,000 \times \mathrm{g}$, and the supernatant was removed carefully. The pellets were air-dried for $45 \mathrm{~min}$ and resuspended in TEAB buffer $(100 \mu \mathrm{L}, 100 \mathrm{mM})$ and digestion solution $(0.4 \mu \mathrm{g} / \mathrm{mL}$ trypsin in $10 \mathrm{mM} \mathrm{HCl}, 7.5 \mu \mathrm{L})$. The digestion was performed at $37^{\circ} \mathrm{C}$ overnight.

\section{TMT-labeling}

The tryptic peptide solution was centrifuged and labeled with neutron-encoded isobaric mass tagging reagents (TMT10) according to the manufacturer's description but using half the amount of labeling reagent. Briefly, $82 \mu \mathrm{L}$ of anhydrous acetonitrile were added to each $0.8 \mathrm{mg}$ of TMT label reagent aliquot (TMT10plex). Of the respective TMT reagent solution, $41 \mu \mathrm{L}$ were transferred to the peptide sample of the respective DMSO control (V1-10). Samples were briefly vortexed directly after addition. For the compound-treated samples, $100 \mu \mathrm{L}$ were transferred to the respective remaining TMT reagent. Samples were briefly vortexed directly after addition. Samples were incubated for $2 \mathrm{~h}$ at room temperature Afterwards, $8 \mu \mathrm{L}$ of $5 \%$ hydroxylamine were added to the samples, and the reaction was quenched by incubating the samples for $15 \mathrm{~min}$. Of each compound-treated labeled sample, $120 \mu \mathrm{L}$ were combined into one sample, and $120 \mu \mathrm{L}$ of each DMSO-treated labeled sample were combined to a second one. Both samples were concentrated by vacuum centrifugation $\left(30^{\circ} \mathrm{C}\right.$, max. speed) until a dry white pellet was visible.

\section{Peptide Identification by Nano-LC-MS/MS}

Prior to nanoHPLC-MS/MS analysis, samples were divided into 10 fractions on a C18 column using high $\mathrm{pH}$ conditions to reduce the complexity of the samples and thereby increase the number of quantified proteins. For this purpose, both samples were dissolved in $120 \mu \mathrm{L} 20 \mathrm{mM} \mathrm{NH}_{4} \mathrm{HCO}_{2}$ solution at $\mathrm{pH} \mathrm{11,} \mathrm{followed} \mathrm{by} \mathrm{incubation} \mathrm{in} \mathrm{an} \mathrm{ultra-sonicator} \mathrm{for} \mathrm{ca.} 2 \mathrm{~min}$, vortexing for $1 \mathrm{~min}$, and centrifugation at 13,000 rpm and room temperature for $3 \mathrm{~min}$. Subsequently, $50 \mu \mathrm{L}$ of supernatant were injected onto an XBridge C18 column (130 $\AA, 3.5 \mu \mathrm{m}, 1 \mathrm{~mm}$ x $150 \mathrm{~mm})$ using a U3000 capHPLCSystem. Separation was performed at a flow rate of $50 \mu \mathrm{L} / \mathrm{min}$ using $20 \mathrm{mM}$ aq. $\mathrm{NH}_{4} \mathrm{HCO}_{2}$ solution (pH 11) as solvent $\mathrm{A}$ and a mixture of aq. $20 \mathrm{mM} \mathrm{NH}_{4} \mathrm{HCO}_{2}$ solution (pH 11) with acetonitrile (2:3) as solvent B. Separation conditions were $95 \%$ solvent A / $5 \%$ solvent B for 15 min, to desalt the samples, followed by a linear gradient up to $25 \%$ for $5 \mathrm{~min}$ and a second linear gradient up to $100 \%$ solvent $\mathrm{B}$ for $60 \mathrm{~min}$. Afterwards, the column was washed with $100 \%$ solvent B for $20 \mathrm{~min}$ and re-equilibrated to the starting conditions. Detection was carried out at a valve length of $214 \mathrm{~nm}$. The eluate between 10 and $80 \mathrm{~min}$ was fractionated into $10\left(1^{\text {st }}\right.$ fraction $20 \mathrm{~min}, 2^{\text {nd }}$ fraction $10 \mathrm{~min}, 3^{\text {rd }}-8^{\text {th }}$ fraction $5 \mathrm{~min}$ each, $9^{\text {th }}$ fraction $10 \mathrm{~min}, 10^{\text {th }}$ fraction $\left.25 \mathrm{~min}\right)$. Each fraction was concentrated by vacuum centrifugation $\left(30^{\circ} \mathrm{C}\right.$, max. speed) until complete dryness and subsequently subjected to nanoHPLC-MS/MS analysis.

For nanoHPLC-MS/MS analysis, samples were dissolved in $10 \mu \mathrm{L}$ of $0.1 \%$ aq. TFA. Of this solution, $4 \mu \mathrm{L}$ were injected into a UltiMate $^{\mathrm{TM}} 3000$ RSLCnano system online-coupled to a $\mathrm{Q}$ Exactive $^{\mathrm{TM}}$ Plus Hybrid Quadrupole-Orbitrap Mass Spectrometer, which was equipped with a nanospray source (Nanospray Flex Ion Source), using a standard coated SilicaTip (ID $20 \mu \mathrm{m}$, Tip-ID $10 \mu \mathrm{M}$ ). All solvents were LC-MS grade. For desalting, samples were injected into a pre-column cartridge $(5 \mu \mathrm{m}$, $100 \AA, 300 \mu \mathrm{m} \mathrm{ID} * 5 \mathrm{~mm}$ ) using $0.1 \%$ TFA in water as eluent at a flow rate of $30 \mu \mathrm{L} / \mathrm{min}$. Desalting was performed for $5 \mathrm{~min}$ with eluent flow to waste followed by back-flushing of the sample during the whole analysis from the pre-column to the PepMap100 RSLC C18 nano-HPLC column ( $2 \mathrm{~mm}, 100 \AA$, $75 \mathrm{~mm} \mathrm{ID} \times 50 \mathrm{~cm}$, nanoViper) using a linear gradient of water/ACN (containing $0.1 \% \mathrm{v} / \mathrm{v} \mathrm{HCOOH}$ ) 95:5 $\rightarrow$ 60:40 during $125 \mathrm{~min}$ using a flow rate of $300 \mathrm{~nL} / \mathrm{min}$. Afterwards, the column was washed (95\% solvent B) and re-equilibrated to starting conditions.

Mass range of $\mathrm{m} / \mathrm{z}=300-1650$ was acquired with a resolution of 70,000 for full scan, followed by up to ten high energy collision dissociation (HCD) MS/MS scans of the most intense at least doubly charged ion peaks using a resolution of 35,000 and an NCE energy of 35\%. 
Data evaluation was performed using MaxQuant software (v.1.5.3.30) (Cox and Mann, 2008) including the Andromeda search algorithm and searching the human reference proteome of the Uniprot database. The search was performed for full enzymatic trypsin cleavages allowing two miscleavages. For protein modifications, carbamidomethylation was chosen as fixed and oxidation of methionine and acetylation of the N-terminus as variable modifications. For relative quantification, the type "reporter ion MS2" was chosen and for all lysines and peptide N-termini, 10plex TMT labels were defined. The mass accuracy for first and second search of full mass spectra was set to $20 \mathrm{ppm}$ and $4.5 \mathrm{ppm}$, respectively and to $20 \mathrm{ppm}$ for MS/MS spectra. The false discovery rates for peptide and protein identification were set to $1 \%$. Only proteins for which at least two peptides were quantified were chosen for further validation. Relative quantification of proteins was carried out using the reporter ion MS2 algorithm implemented in MaxQuant. All experiments were performed in biological triplicates.

\section{Melting Curve Calculation}

To determine the melting point shifts between compound- and DMSO-treated samples of each protein, an in-house developed Excel-Macro was used. Briefly, denaturation changes at different temperatures were tracked using the reporter ion intensity and observed in relation to the lowest temperature; the reporter ion intensity for lowest temperature was normalized to 1 .

The relative fold changes of melting temperatures were calculated as a function of temperature using the Boltzmann equation:

$$
\mathrm{y}=\text { bottom plateau }+\frac{\text { top plateau }- \text { bottom plateau }}{1+\mathrm{e}^{-\left(\frac{\mathrm{a}}{\mathrm{T}}\right)-\mathrm{b}}}
$$

Equation 1. The sigmoidal trend of the measured intensities was fitted with the following equation using an iterative working macro in Microsoft Excel. Top plateau is fixed to one; bottom plateau is a protein specific constant that defines the maximal denaturation; $a$ and $b$ are constants which describe the curve progression.

The melting point of a protein was defined as the temperature at which half of the protein has been denatured. This point corresponds to the inflection point of the curve, the highest slope of the curve which is defined as the value of the first derivative.

For hit identification, following requirements were defined and had to be fulfilled for all replicates: (1) Proteins had a calculated $\Delta \mathrm{T}_{\mathrm{m}}$ in all replicates; (2) were either stabilized or destabilized in all replicates; (3) had a mean $\Delta \mathrm{Tm} \geq \pm 2{ }^{\circ} \mathrm{C}$ or an intensity shift of $\geq 10 \%$ at the highest temperature; and (4) had a relative intensity of $<0.4$ at the highest temperature.

\section{In-Cell Cellular Thermal Shift Assay (CETSA)}

Two T75 cell culture flasks were seeded with each 6x105 MCF7\#2011 cells in $12 \mathrm{~mL}$ DMEM and incubated at $37^{\circ} \mathrm{C}$ and $5 \% \mathrm{CO}_{2}$ for three days. The media was subsequently removed and replaced with $3 \mathrm{~mL}$ medium containing either $50 \mu \mathrm{M}$ of Indophagolin (1) or DMSO. After incubation for $1 \mathrm{~h}$ at $37^{\circ} \mathrm{C}$ and $5 \% \mathrm{CO}_{2}$ the medium was removed, and cells were detached using $1.5 \mathrm{~mL}$ trypsin and $1 \mathrm{x} 106$ cells each were collected in $0.6 \mathrm{~mL}$ PBS each. Treated and non-treated cell suspensions were divided into ten aliquots, each $50 \mu \mathrm{L}$ in PCR tubes. The aliquots were individually heated at different temperatures (Eppendorf Mastercycler ep Gradient S). After the heat treatment, $5 \mu \mathrm{L}$ PBS containing 4.4\% NP-40 Alternative were added to each sample and cells lysed by freeze and thaw. The cell lysates were completely transferred to polycarbonate tubes and centrifuged (Beckman Optima MAX-TL) at 100,000 g, $4^{\circ} \mathrm{C}$ for $25 \mathrm{~min} .16 \mu \mathrm{L}$ of each supernatant were added with $4 \mu \mathrm{L}$ of $5 \mathrm{x}$ loading buffer and incubated for $5 \mathrm{~min}$ at $95^{\circ} \mathrm{C}$, before samples were analyzed by Immunoblotting. Proteins were separated by SDSPAGE, and transferred to PDVF membrane using wet transfer. The membranes were blocked with Intercept ${ }^{\circledR}$ Blocking Buffer (PBS; Li-Cor) for $1 \mathrm{~h}$ and incubated with the primary antibody rabbit antiP2X4 antibody (\#ab243734) (Intersept ${ }^{\circledR}$ blocking buffer containing $0.2 \%$ Tween-20) at $4^{\circ} \mathrm{C}$ over night. After washing with PBS-T (PBS containing $0.1 \%$ Tween) the membrane was incubated with the 
secondary antibody coupled to IRDye ${ }^{\circledR} 800 \mathrm{CW}$ (Donkey anti-Rabbit IgG, Li-COR) for $1 \mathrm{~h}$, in Intersept ${ }^{\circledR}$ blocking buffer containing $0.2 \%$ Tween- 20 and $0.1 \%$ SDS at room temperature. Membranes were washed with PBS-T, then PBS before images were taken (Bio-Rad ChemiDoc ${ }^{\mathrm{TM}}$ MP Imaging System).

\section{In-Cell Isothermal dose response experiment (ITDR)}

Two six well plates were seeded with each $3 \times 10^{5}$ MCF7/LC3 cells in $2 \mathrm{~mL}$ MEM per well and incubated at $37^{\circ} \mathrm{C}$ and $5 \% \mathrm{CO}_{2}$ overnight. The media was subsequently removed and replaced with $0.5 \mathrm{~mL}$ medium containing either different concentrations of Indophagolin (1) or DMSO. After incubation for $1 \mathrm{~h}$ at $37^{\circ} \mathrm{C}$ and $5 \% \mathrm{CO}_{2}$ the medium was removed and cells were detached using $200 \mu \mathrm{L}$ trypsin and collected in $0.5 \mathrm{~mL}$ MEM each. Treated and non-treated cell suspensions were centrifuged ( $350 \mathrm{~g}, 5 \mathrm{~min})$, and resuspended in $50 \mu \mathrm{L}$ PBS in PCR tubes. The samples were heated at $73.1^{\circ} \mathrm{C}$ (Eppendorf Mastercycler ep Gradient S). After the heat treatment, $5 \mu \mathrm{L}$ PBS containing 4.4\% NP-40 Alternative were added to each sample and cells lysed by freeze and thaw. The cell lysates were completely transferred to polycarbonate tubes and centrifuged (Beckman Optima MAX-TL) at 100,000 g, $4^{\circ} \mathrm{C}$ for $25 \mathrm{~min} .16 \mu \mathrm{L}$ of each supernatant were added with $4 \mu \mathrm{L}$ of $5 \mathrm{x}$ loading buffer and incubated for $5 \mathrm{~min}$ at $95^{\circ} \mathrm{C}$, before samples were analyzed by Immunoblotting. Proteins were separated by SDS-PAGE, and transferred to PDVF membrane using wet transfer. The membranes were blocked with Intercept ${ }^{\circledR}$ Blocking Buffer (PBS; Li-Cor) for $1 \mathrm{~h}$ and incubated with the primary antibody rabbit anti-P2X4 antibody (\#ab243734) (Intersept ${ }^{\circledR}$ blocking buffer containing $0.2 \%$ Tween-20) at $4^{\circ} \mathrm{C}$ over night. After washing with PBS-T (PBS containing $0.1 \%$ Tween) the membrane was incubated with the secondary antibody coupled to IRDye ${ }^{\circledR} 800 \mathrm{CW}$ (Donkey anti-Rabbit IgG, Li-COR) for $1 \mathrm{~h}$, in Intersept ${ }^{\circledR}$ blocking buffer containing $0.2 \%$ Tween-20 and $0.1 \%$ SDS at room temperature. Membranes were washed with PBS-T, then PBS before images were taken (Bio-Rad ChemiDoc ${ }^{\mathrm{TM}}$ MP Imaging System).

\section{QUANTIFICATION AND STATISTICAL ANALYSIS}

Data analysis of the autophagy inhibition phenotypic screen was performed using a modified configuration of the granularity assay of MetaXpress Cell Analysis Software. MS-data evaluation for TPP experiments was performed using MaxQuant software. All other analyses were performed in GraphPad Prism 5.0. Replicate number and definition of $\mathrm{n}$ is indicated in figure legends.

Error was calculated for all measurements in order to confirm that differences that were measured in the presence and absence of antibiotic are statistically meaningful. For example, in Figures 3, 5, and S4, error bars on the absorbance values are derived from at least three replicates. All reported measurements were found to be statistically significant by the criterion of non-overlapping error unless otherwise stated.

\section{DATA AND CODE AVAILABILITY}

Any of the raw data used in this work will be made available upon request. 


\section{FIGURE}

A<smiles>O=C(C1CC1)N1CCc2cc(Br)c(S(=O)(=O)Nc3ccc(Cl)c(C(F)(F)F)c3)cc21</smiles>

C

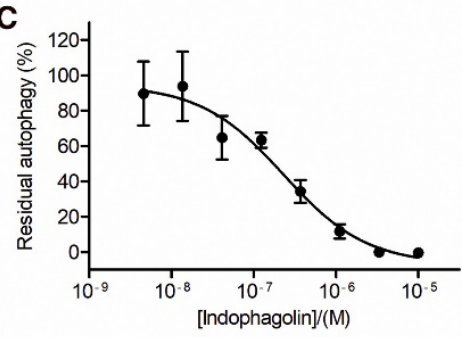

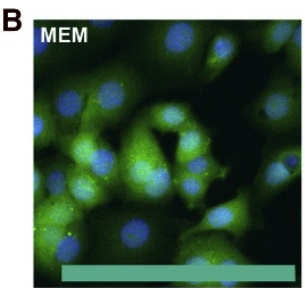

D MEM

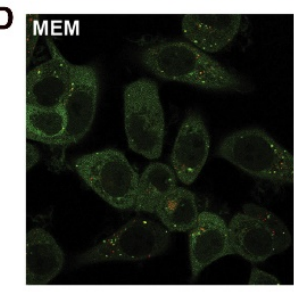

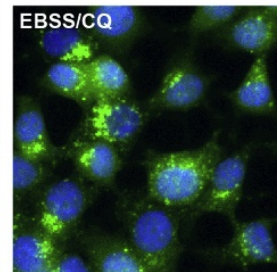
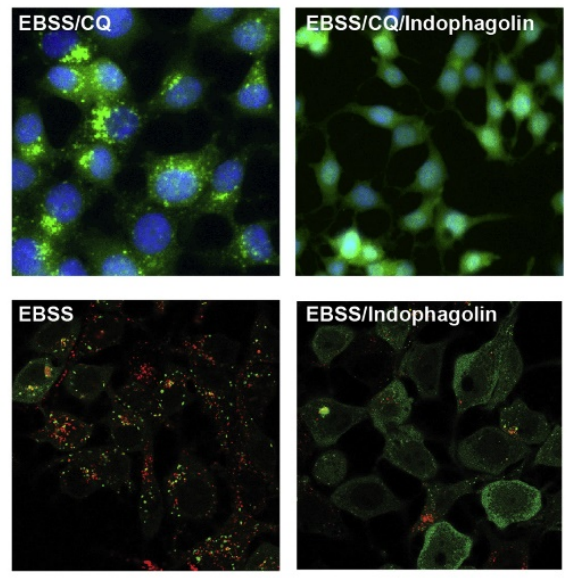

E

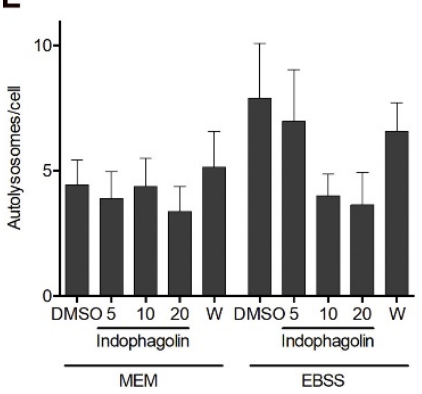

$F_{2}$

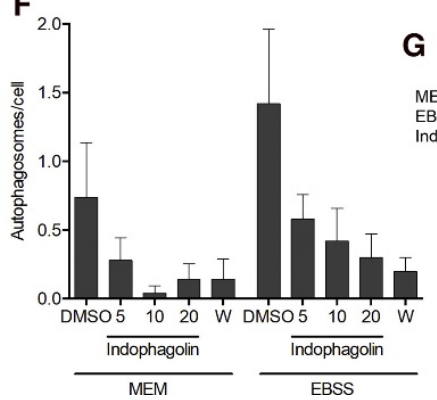

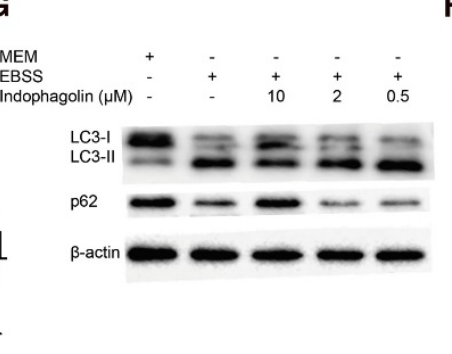

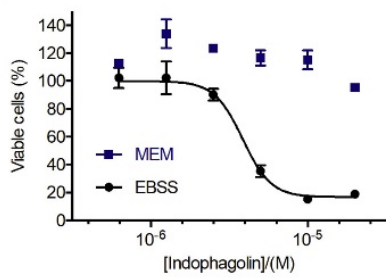

Figure 1. Indophagolin potently inhibits autophagy.

(A) Chemical structure of indophagolin.

(B) Inhibition of autophagosome formation upon treatment with indophagolin $(10 \mu \mathrm{M})$ in a phenotypic assay using MCF7 cells (nuclei stained with Hoechst [blue]) stably expressing eGFP-LC3 (green) ( $\mathrm{n}=6$, each in $\mathrm{N}=3$; representative images shown); scale bar: $50 \mu \mathrm{M}$.

(C) Residual autophagy upon treatment with indophagolin quantified by the ratio of eGFP puncta compared with the MEM and EBSS controls, showing a dose-dependent inhibition of autophagy in starved conditions (representative image shown).

(D) Effect of indophagolin $(20 \mu \mathrm{M})$ on autophagosomes (yellow) and autolysosomes (red) on starved MCF7 cells stably expressing mCherry-eGFP-LC3 $(\mathrm{N}=5$, representative images shown).

(E) Quantification of mCherry puncta in the mCherry-eGFP-LC3 assay, showing a decrease in the number of autolysosomes in starved conditions.

(F) Quantification of eGFP puncta in the mCherry-eGFP-LC3 assay, showing a decrease in the number of autophagosomes in starved conditions upon treatment with indophagolin; indophagolin concentrations shown in $\mu \mathrm{M}$; wortmannin concentration $=500 \mathrm{nM}$.

(G) Effect of indophagolin on the autophagy-induced accumulation of lipidated LC3 (LC3-II) and degradation of p62 in MCF7-eGFP-LC3 cells as assessed by Western Blotting ( $\mathrm{n}=4$, representative image shown).

(H) Effect of indophagolin on cell viability in fed and starved MCF7 cells; MCF7 cells in either full medium (MEM; blue) or under starvation conditions (EBSS; black) were treated with indophagolin, and the viability was determined after 48 h by means of a WST-1 reagent $(n=3$, representative graph shown). 
Data shown are mean values \pm SEM. $\mathrm{CQ}=$ chloroquine; $\mathrm{MEM}=$ minimal essential medium; $\mathrm{W}=$ wortmannin; WST $=$ water-soluble tetrazolium salt. 

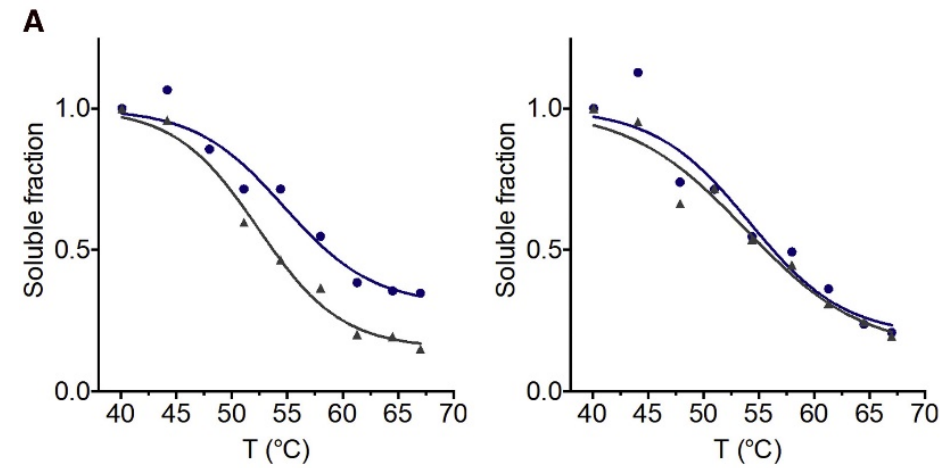

B $\quad$ Temperature $\left[{ }^{\circ} \mathrm{C}\right] \quad\left[\begin{array}{llllllllll}51.4 & 56.4 & 61.7 & 66.1 & 69.6 & 73.1 & 78.1 & 85.9 & 89.2\end{array}\right.$

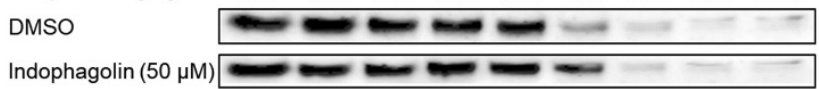

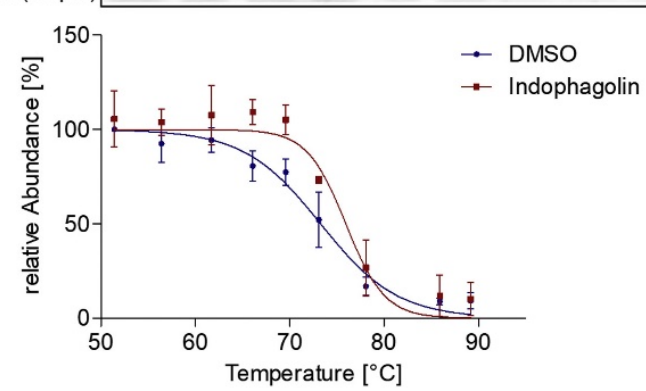

$\begin{array}{lllllllllll}\text { C Indophagolin }[\mu \mathrm{M}] & \mathrm{DMSO} & 50 & 25 & 12.5 & 6.3 & 3.1 & 1.7 & 0.8 & 0.4 & \mathrm{DMSO}\end{array}$

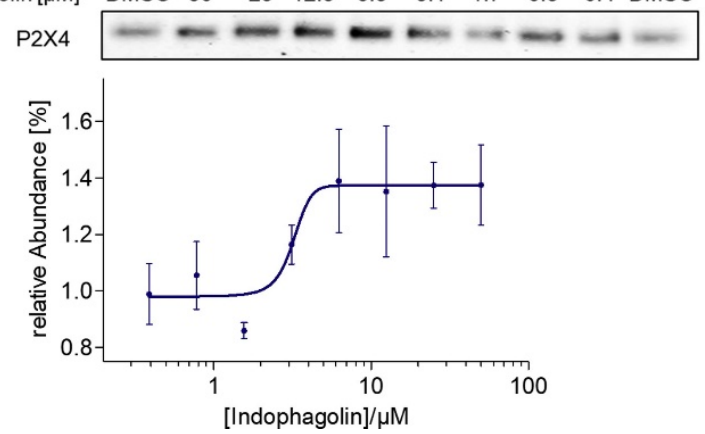

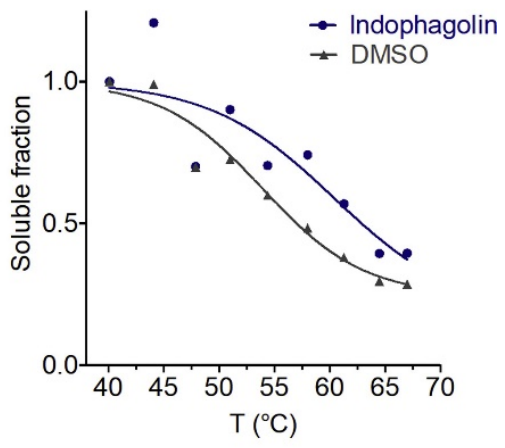

D
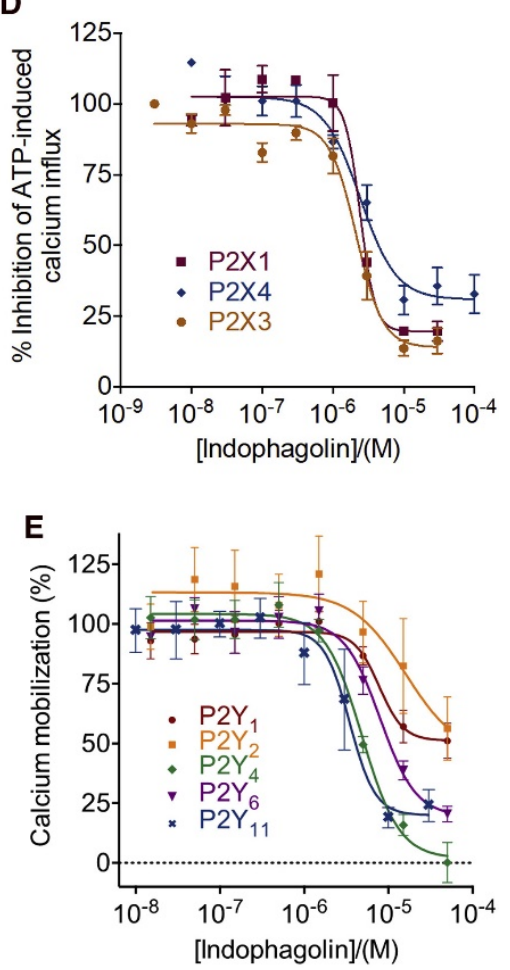

Figure 2. Indophagolin Targets Purinergic Receptors

(A) Melting curves of P2X4 generated by TPP of MCF7-eGFP-LC3 cells upon incubation with indophagolin (blue) or DMSO (grey) for each replicate.

(B) Thermal stabilization of P2X4 by indophagolin in intact MCF7 cells and corresponding quantification as assessed by Western Blotting $(\mathrm{n}=3$, representative images shown).

(C) Dose-dependent stabilization of P2X4 by indophagolin in intact MCF7 cells and corresponding quantification as assessed by ITDRF ( $\mathrm{n}=3$, representative images shown). $\mathrm{IC}_{50}=3.2 \pm 0.6 \mu \mathrm{M}$

(D) Concentration-response curves of indophagolin at various human P2XRs determined using a calcium influx assay with recombinant $1321 \mathrm{~N} 1$ astrocytoma cells. ATP at concentrations corresponding to their $\mathrm{EC}_{80}$ were used for receptor activation $(1.2 \mu \mathrm{M}$ for P2X1, $80 \mathrm{nM}$ for P2X3, $180 \mathrm{nM}$ for P2X4) (n $=2-3$, each in $\mathrm{N}=2$ ).

(E) Concentration-response curves of indophagolin at various human P2YRs determined using calcium mobilization assays with recombinant $1321 \mathrm{~N} 1$ astrocytoma cells. Agonists at concentrations corresponding to their $\mathrm{EC}_{80}$ were used for receptor activation (150 nM ADP for P2 $\mathrm{Y}_{1}, 150 \mathrm{nM}$ UTP for $\mathrm{P}_{2} \mathrm{Y}_{2}, 250 \mathrm{nM}$ UTP for P2Y $4,3 \mu \mathrm{M}$ UDP for P2 $\mathrm{Y}_{6}, 8.6 \mu \mathrm{M}$ ATP for P2 $\left.\mathrm{Y}_{11}\right)(\mathrm{n}=4$, each in $\mathrm{N}=2)$. Data shown are mean values \pm SEM. 
Table 1: Activities of Selected Indophagolin-Derived Analogs for Starvation-Induced Autophagy, Measured in the Phenotypic Screen

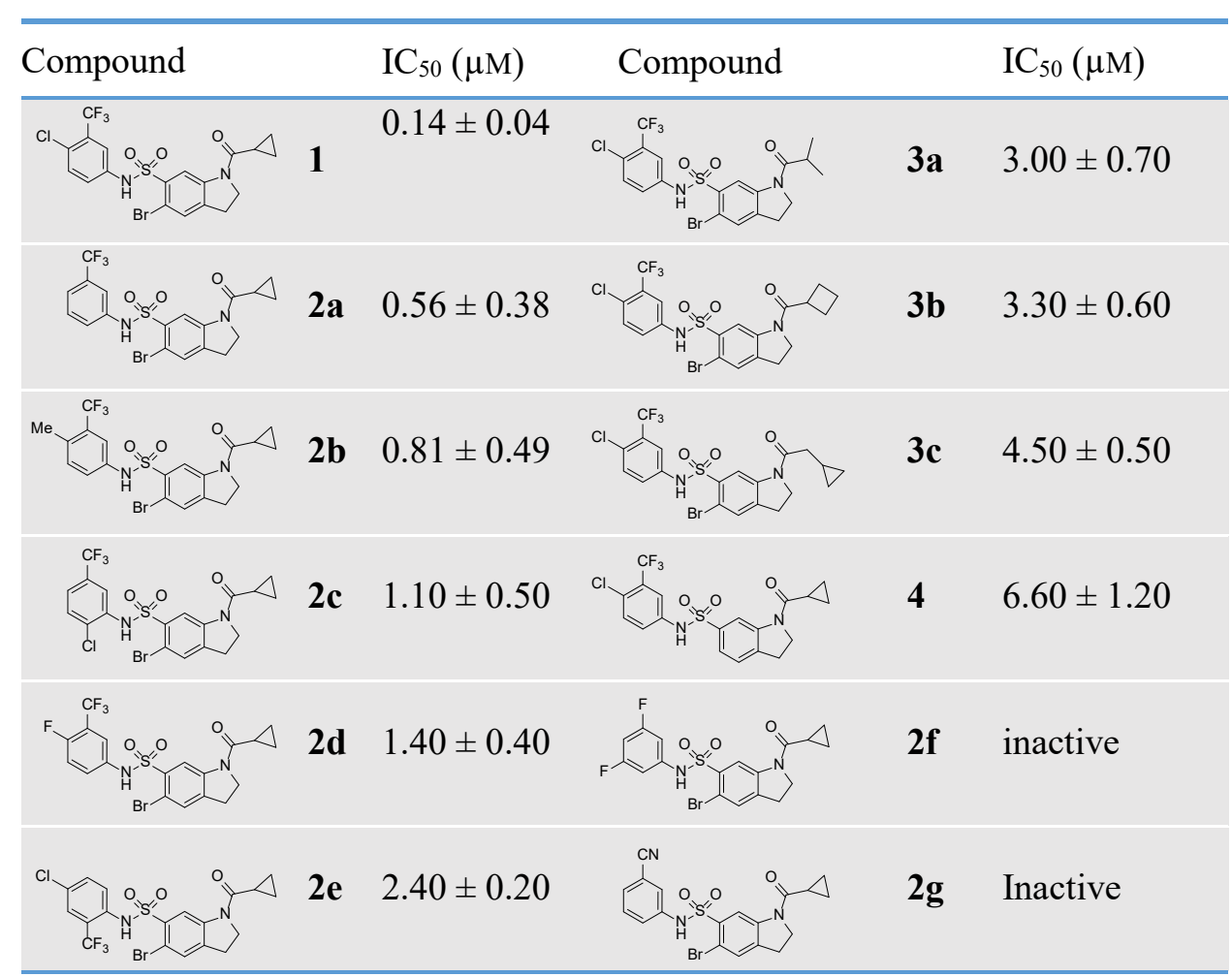

Data shown are mean values \pm SEM $(\mathrm{N} \geq 3)$. 
Table 2: Activity of Indophagolin on a Panel of Purinergic Receptors

\begin{tabular}{|c|c|c|}
\hline Receptor & $\mathrm{IC}_{50} \pm \operatorname{SEM}(\mu \mathrm{M})$ & $\%$ Inhibition \\
\hline $\mathrm{P} 2 \mathrm{X} 1$ & $2.40 \pm 0.34$ & N/A \\
\hline $\mathrm{P} 2 \mathrm{X} 2$ & $>10$ & $13 \pm 3$ \\
\hline $\mathrm{P} 2 \mathrm{X} 3$ & $3.49 \pm 0.84$ & N/A \\
\hline $\mathrm{P} 2 \mathrm{X} 4$ & $2.71 \pm 0.54$ & N/A \\
\hline $\mathrm{P} 2 \mathrm{X} 7$ & $>10$ & $17 \pm 3$ \\
\hline $\mathrm{P}_{2} \mathrm{Y}_{1}$ & $\approx 50$ & $49 \pm 7$ \\
\hline $\mathrm{P}_{2} \mathrm{Y}_{2}$ & $\approx 50$ & $44 \pm 13$ \\
\hline $\mathrm{P} 2 \mathrm{Y}_{4}$ & $4.89 \pm 0.18$ & $\mathrm{~N} / \mathrm{A}$ \\
\hline $\mathrm{P}_{2} \mathrm{Y}_{6}$ & $15.4 \pm 2.8$ & N/A \\
\hline $\mathrm{P} 2 \mathrm{Y}_{11}$ & $3.40 \pm 1.08$ & N/A \\
\hline $\mathrm{P} 2 \mathrm{Y}_{12}$ & $\geq 10^{\mathrm{a}}$ & $38 \pm 9$ \\
\hline
\end{tabular}

Activity against $\mathrm{P} 2 \mathrm{X}$ and $\mathrm{P} 2 \mathrm{Y}$ receptors was assessed by calcium influx and mobilization assays, respectively, with recombinant $1321 \mathrm{~N} 1$ astrocytoma cells unless otherwise stated. Data shown are mean values \pm SEM or $\%$ inhibition at $10 \mu \mathrm{M}(\mathrm{P} 2 \mathrm{X}$ receptors) or $50 \mu \mathrm{M}$ (P2Y receptors) $(\mathrm{n}=2-4$, each in $\mathrm{N}=2$ ).

aPotency at the $\mathrm{G}_{\mathrm{i}}$-coupled $\mathrm{P} 2 \mathrm{Y}_{12} \mathrm{R}$ was determined using a $\beta$-arrestin translocation assay. 